Article

\title{
Sustainable Development, Wellbeing and Material Consumption: A Stoic Perspective
}

\author{
Kai Whiting ${ }^{1, *}$, Leonidas Konstantakos ${ }^{2}$, Angeles Carrasco ${ }^{3}$ (D) and Luis Gabriel Carmona ${ }^{1,4}$ \\ 1 MARETEC-LARSyS, Instituto Superior Técnico, Universidade de Lisboa, Avenida Rovisco Pais 1, \\ 1049-001 Lisboa, Portugal; lugacapa@gmail.com or gabrielcarmona@tecnico.ulisboa.pt \\ 2 School of International and Public Affairs, Florida International University, 11200 SW 8th St, Miami, \\ FL 33199, USA; lkons001@fiu.edu \\ 3 Mining and Industrial Engineering School of Almadén, Universidad de Castilla-La Mancha, \\ Plaza Manuel Meca 1, 13400 Almadén, Spain; angeles.carrasco@uclm.es \\ 4 Faculty of Environmental Sciences, Universidad Piloto de Colombia, Carrera 9 No. 45A-44, \\ Bogotá 110231, Colombia \\ * Correspondence: kaiwhiting@tecnico.ulisboa.pt or whitingke@yahoo.co.uk; \\ Tel.: +351-21-841-73-66 (ext. 1366)
}

Received: 15 December 2017; Accepted: 7 February 2018; Published: 10 February 2018

\begin{abstract}
Since the introduction of neoclassical economic theory, material wealth and accumulation have been linked to hedonic wellbeing. In turn, Utilitarian notions have generated the belief that infinite growth is not only good but necessary for society to prosper. Unsurprisingly, this belief system has supported the considerable depletion of natural resources and has not always led to social equitability or environmental justice, two pillars of sustainable development. Given these limitations, this paper looks into eudaimonic wellbeing, as defined by Stoicism. The latter originating in Classical Greece and Ancient Rome, has been used throughout the centuries to discuss and support the flourishing of individuals, but has rarely been applied to collective wellbeing. Consequently, we explore whether, and to what extent, this virtue-based philosophy can answer questions regarding the value and the role of material acquisition in societal development, as directed by sustainable policy. We propose the idea that the Stoic emphasis on prudence, self-control, courage and justice, as the only means to achieve "happiness", is intrinsically linked to sustainable wellbeing and that its principles can be used to demonstrate that society does not require limitless growth to flourish.
\end{abstract}

Keywords: environment; eudaimonia; material services; Stoicism; sustainability; wellbeing economics

\section{Introduction}

Material extraction, consumption and disposal are growing concerns within the sustainable development discourse, policy and practice. This is because a considerable number of material flows support the material and energy services on which society and the current economic system depend [1]. Just sixty years ago, relatively few elements were widely used to support most applications, but today complex mixtures of up to two-thirds of the periodic table, have become the norm $[2,3]$. The problem is not the use of materials per se but rather a failure to accommodate/address the environmental or social issues that have occurred as a result of mass extraction. Arguably, this is not just because the system is capitalistic, or even materialistic, but also because it is linear in nature. When linear relationships are combined with an economy established on mass production, consumerism and hedonic principles of wellbeing, it becomes clear that the cyclic processes of Nature are undermined. The relationship between Nature and humankind is also damaged [4]. Furthermore, adherence to, or at least movement towards a circular economy (as opposed to a linear one), does not necessarily 
solve the problem of sustainability, as creating a product that does not address needs still requires energy and will intrinsically lead to exergy destruction [5] without generating societal benefit.

Both Capitalism and Communism apply hedonic notions when it comes to measuring wellbeing, whereby the latter refers to a state of optimal psychological functioning and the opportunity to experience what one deems as important to their personal and collective expression [6]. Hedonic wellbeing, specifically, equates "optimal psychological functioning" with the ability or opportunity to experience pleasure and enjoyment in the physical or emotional sense. It does not necessarily mean, or refer to, the attaining of pleasure for pleasure's sake (hedonism) and is used in this paper as a juxtaposition to eudaimonic pursuits which prize virtue (or the progress towards it) over and even at the expense of comfort [7].

Capitalism, in its simplest form, allows for the "free" market to dictate production, how consumers receive their goods and services and how much they should pay or be paid. Communism, as it developed historically, on the other hand, is built on the notion that the workers should own the means of production and that goods and services should be distributed centrally with the State deciding how much an item should cost and how much the person providing that item must be waged [8]. No doubt, for Lenin, industrialisation was an essential ingredient in a successfully run State-led economy, as evidenced by his statement that communism is Soviet power plus the electrification of the whole country, since industry cannot be developed without electrification [9].

The major difference between the two economic theories, therefore, is with "who" should be involved in the production and distribution of goods and services and how it should be done efficiently. Marxism, likewise is similarly concerned with the "who"-who is exploited (the proletariat) and who is the beneficiary (bourgeois) and how those beneficiaries accumulate wealth and gain an advantage at the former's expense. None of these economic frameworks, outside of issues pertaining to ownership rights (again who owns what and how that ownership is maintained), particularly concern themselves with "what" should be produced or "why", beyond matters linked to profit. It is therefore difficult to see how they can, on their own, offer a particularly satisfactory answer to sustainable development, beyond issues pertaining to labour conditions and ownership, which remain, of course, important considerations that help bring about justice.

Consequently, the economy and its unit of choice, money, should not, as alluded to by Adam Smith himself, be given free rein as the unchecked invisible hand. After all, the economic system is not teleological; in the sense that it does not have reasons, purposes or inclinations. Rather, and to take a Stoic perspective, it is directed by the collective virtue of those that created it. To understand the nature of its direction and make an effort to change it, one should then seek to grasp the concept of societal virtue and how it must come to shape 21st century thought and action.

In this paper and using the concept of material services as a case study, we evaluate the robustness of Stoicism as a philosophical framework, upon being applied to the modern challenge of sustainable wellbeing and development. We do this by examining the role that both modern and ancient forms of Stoic philosophy, its virtue value system and its specific take on eudaimonic wellbeing, could play alongside science, economics and other human endeavours, in aiding the design and propagation of sustainable policies and practices, as an additional and alternative perspective.

Whilst it is true that the question of "To what extent, if any, do material goods contribute to wellbeing?" is explored through other notions of eudaimonia, both ancient and modern, this paper is not evaluating the strength of hedonic vs eudaimonic claims to wellbeing, nor comparing the sustainable value provided by different definitions of eudaimonia. Neither is it comparing or contrasting Stoic thought with political ideologies such as Marxism, although there is a potential benefit in exploring such concepts elsewhere. Here, the paper's scope is solely restricted to exploring whether Stoic eudaimonia, which is only gained through virtue, can provide insight to sustainable development. The authors do not necessarily consider Stoicism to be the "best" or only "worthy" philosophy with which to approach sustainability, instead they explore the merits of its bottom-up framework and its potential contribution to the debate. 


\section{Key Tenets of Stoic Philosophy}

Stoicism is a philosophy of Hellenic origin established by Zeno around 301 BCE. Developed originally out of Cynicism, and particularly influenced by the teaching of Socrates and Plato (the Academics), most of what now constitutes both modern and Ancient Stoic thought comes from the Roman texts of Seneca, Epictetus and Marcus Aurelius, all of which occupy the later Stoa [10,11].

Contemporary schools of Ancient Stoicism included the above, along with Peripatetics (followers of Aristotle), the Epicureans, Cyrenaics and the Skeptics with the key debate centred on whether or not it was "virtue" or "pleasure" that would ultimately lead, or was sufficient in and of its own right to lead, a person to experience a life worth living, eudaimonia. This term, popularised by Aristotle, is commonly translated as (and encompasses feelings of) fulfilment, flourishing, wellbeing and happiness. In all cases, its Ancient interpretation focuses on virtue ethics, as derived by Aristotle's categorisation of the virtues into the moral and intellectual [12]. For Stoics, virtue is a type of "knowledge" which ultimately leads to a fully coherent rational person who acts with (and does not just think about) prudence, self-control, courage and justice on every humanly conceivable potentiality. The person(s) who holds knowledge of and assents to the right cognitive impression on each and every conceivable occasion, not for its, or their, own sake but because it is the right thing to do is said to be the ideal Stoic, or the Sage.

Such a person shows eudaimonia to exist empirically and does not just infer that it does in the mind's eye or another abstract form. This is because the ontological premise of Stoicism is intrinsically grounded in physical reality and thus action, not simply thought.

Followers of Modern Stoicism likewise emphasise eudaimonia over hedonistic concerns (externalities) and continue in aim and practice, like their forefathers before them, to progress towards that state, which they characterise as a life worth living [11]. Consequently, the philosophy has been heavily focused and applied to personal endeavours such as Albert Ellis' Stoic-inspired Cognitive Behavioural Therapy [13] or Irvine's [14], Robertson's [15] and Brown's [16] guide to "happiness" and fulfilment. All such ideas are built on the assumption that the best human life can only be achieved by, and consists of developing and exercising virtue [17], where the latter term is taken to mean:

"A form or expertise or skill, knowledge how to live well in every way, a form of knowledge that shapes the whole personality and life."-Gill [18]

For a Stoic, virtue alone is said to be necessary and sufficient. It is tied in a causal way to eudaimonia because, unlike any externals (health, material goods, pleasure, power, reputation and societal position), it can in and of itself bring about the highest level of fulfilment [18]. It is something that always and necessarily benefits humanity and, thus, its absence is the only guarantee of unhappiness and a lack of wellbeing, through an unhealthy (non-virtuous) state of mind [19]. This may seem strong, or even counter-intuitive but, as has been frequently noted by Stoics [20,21], wealth, health and absence of war do not necessarily constitute wellbeing, in the sense that one can be rich, free of disease and living at a time of a peace and still be utterly miserable (wretched) and unfulfilled. Consequently, and according to Clark [22], mature Stoics recognise that external goods are illusions and incapable of directly contributing to eudaimonia. Although they can support appropriate action they may also distract from the four Stoic virtues: justice, courage, self-control/moderation (temperance) and practical wisdom (prudence) —all of which are interconnected, obtainable and must be expressed in the physical. The latter point is an especially important consideration under a Stoic framework, for one cannot, according to Daws [23], confess to be a follower of Stoicism (prokoptontes meaning a "progressor", which is typically used in the plural, prokopton) if one does not demonstrate their adherence to such virtues. For example, in order to be considered just, a Stoic must uphold a moral and legal sense of justice and be just in their distribution of good and rights. On an individual level, they should be able to demonstrate progress towards virtue, and through both their thoughts and actions keep virtue as a target in mind, even if they are not ultimately able to hit it (fully achieve virtue). 
The above idea, especially when applied to collective progress towards virtue, is linked to the Stoic concept of cosmopolitanism, often explored through the metaphor of the human body, where every individual contributes as a limb, to support that which cannot prosper on its own or operate under its own terms [24]. Likewise, this metaphor is supported by the Stoic philosopher Hierocles' concentric circles which make up the whole of humanity and, taking Long and Sedley's [25] interpretation, require a Stoic practitioner to move each successive circle into the centre (the inner most circle representing the self), so as to make sure that each and every human being comes within the circle of care, concern and community [26]. The embodiment of this tenet, amongst other things, has traditionally been and continues to be a "commitment to public life and the engagement with society" (Sullivan in Jules [27]). This is because a Stoic is publicly committed "to being useful, to helping others, to take care, not only of ourselves, but of everyone in general and of each one in particular" (Seneca, On Clemency 3.3, translation by Hadot [28]). Consequently, Daws [23] argues, a Stoic has a moral calling to actively support all of humankind in reaching for the lofty rational heights they themselves should aspire towards.

It is worth stating that the dichotomy of "egoism" and "altruism" does not fit the Stoic framework, or thought process, because of the complementary belief that one should "follow nature" and that rational neurotypical humans are fundamentally social in nature $[29,30]$. As such, what is good for the human being is being social and a member of the whole [24]. This Stoic belief is supported by Epictetus statement in Discourses 2:10 (modified from Oldfather [31]):

"Treat nothing as a matter of private profit ... if they (the hand or foot, as the metaphor for human individuals) had the faculty of reason and understood the constitution of nature, they would never exercise choice or desire in any other way but by reference to the whole."

Consequently, whilst Stoicism may not fully demand (in the way a religious doctrine might) a sense of shared community and civic responsibility, it does strongly call its followers to participate as active members of society. It does state the moral obligation to express virtue towards others and to act upon concerns held towards animals, plants and the wider environment $[17,22]$, in recognition of the fact that humankind is not the highest entity of the universe, just perhaps the most rational [32]. This understanding results from the Stoic concept of oikeiôsis, which describes humanity's affinity/appropriation with Nature, as first dictated by a self-preserving instinct and later refined through reason, a position that Pigliucci [33] argues is highly compatible with modern findings in both evolutionary and cognitive science (e.g., [34]). Another key consideration, linked to both Stoic affinity with and the moral obligation towards Nature, concerns the logos, but this lies beyond the scope of the paper.

\section{Different Notions of Eudaimonia}

As alluded to in the introduction to this paper, Stoicism is one of many modern and ancient philosophies/perspectives focused on exploring and living eudaimonia, a holistic interpretation of the "good life", most readily associated with Aristotle. The Aristotelian view of eudaimonic wellbeing, as with Stoicism, centres on virtue, with the important caveat that it was beyond the reach of women, the uneducated, poor or slaves [35]. Stoics, for their part, contested from the very beginning that the ability to act virtuously was not contingent on social status, gender or anything that can be ascribed externally to a person's progress towards virtue. This was in sharp contrast to Aristotle who put forward the view that certain external aspects (including those aforementioned characteristics) were not only important elements but absolutely essential for eudaimonia to be achieved and maintained [36].

Conceptually, eudaimonia was not originally restricted to the wellbeing of the individual. Indeed, Aristotle, the Stoic founder Zeno and his successor Cleanthes, promoted a State-backed model of the "good life" with politics and institutionalised education providing the means by which one could instil virtue [37]. Zeno's Republic, far from being a copy of Aristotle's elitism was of a more "Communist" persuasion, perhaps as uncomfortably so for the modern reader as it was for the later Roman Stoics 
who turned away from the more unpalatable aspects of shared property and communal directed State governance. In this respect, as Stoicism developed, alongside other Hellenistic philosophies rooted in Socrates, Plato and Aristotle, it distanced itself from the collective creation of a virtuous State and evolved into an altogether more personal journey, whereby virtue was to be achieved from a bottom-up decision rather than a top-down political strategy or policy.

A typical bottom-up philosophical comparison of Stoicism involves the wellbeing ideas presented within the Epicurean framework. For Epicurus, the founder of the philosophy that bears his name, it was rational pleasure, obtained through a carefully controlled life, and not virtue, that benefits a person [38]. Consequently, for an Epicurean it is the seeking of that which is pleasurable and the avoidance of pain, which results in the highest attainment of wellbeing [39]. However, and despite appearances, their focus was not on achieving the "modern" or Cyrenaic definition of hedonism but rather ataraxia, a state Epicurus described as the "untroubled and tranquil condition for the soul" [40]. This state required prudence and was achieved through relative seclusion, austerity and the shying away from public life.

Modern developments and re-workings of the definition of eudaimonia tend to emphasise the subjective and the personally defined vision, as most readily seen in Sen [41,42] who argues that questions relating to wellbeing should be framed in terms of an individual's "capability" or "opportunity" to live a "good life". For Sen, the ability to live such an existence is viewed through the lens of an individual's ability to freely succeed in doing what they chose to do, being who they choose to be and pursuing what he or she could have done, according to their own idiosyncrasies [43]. Under Sen's framework the personal freedom to positively choose one's lifestyle and preferences is an integral part of achieving eudaimonia, which is in itself only one component of a person's life goals and commitments, some of which are not related to personal wellbeing at all $[41,44]$. Table 1 provides a brief comparison of some of the different schools of ethics and their interpretation of wellbeing, and how this may be applied to sustainable development.

Table 1. Philosophical perspectives of wellbeing and their insights into sustainable development.

\begin{tabular}{|c|c|c|c|}
\hline School/Perspective & $\begin{array}{c}\text { Type of } \\
\text { Wellbeing }\end{array}$ & Wellbeing Obtained Through & $\begin{array}{l}\text { Insight Stoicism Provides to Their } \\
\text { View on Sustainable Wellbeing }\end{array}$ \\
\hline Cyrenaic & Hedonic & $\begin{array}{l}\text { Pleasures of the past, present } \\
\text { and future. Pain is to be avoided. } \\
\text { The maximisation of pleasure is } \\
\text { the end goal and must be strived } \\
\text { for. In certain cases, stealing is } \\
\text { permissible. The obtaining of } \\
\text { knowledge regarding the "good } \\
\text { life" is impossible. Eudaimonic } \\
\text { wellbeing is refuted. }\end{array}$ & $\begin{array}{l}\text { Cyrenaic thinking is the } \\
\text { antithesis of sustainable development. } \\
\text { If every individual was to maximise } \\
\text { their wellbeing through the } \\
\text { unfettered accumulation of material } \\
\text { goods without concern for what really } \\
\text { constitutes wellbeing, humanity could } \\
\text { not be sustained. }\end{array}$ \\
\hline Epicurean & Hedonic & $\begin{array}{l}\text { The rational maximisation of } \\
\text { pleasure and minimalisation of } \\
\text { pain. This is best achieved } \\
\text { through social seclusion, austerity } \\
\text { and the shying away of public life. } \\
\text { The repetition of readily } \\
\text { remembered pieces of wisdom is a } \\
\text { key method with which to combat } \\
\text { unwelcome states of being } \\
\text { and emotions. }\end{array}$ & $\begin{array}{l}\text { The Epicurean lifestyle choice } \\
\text { was one of rational pleasure derived } \\
\text { through communal simplicity and } \\
\text { isolation. Although such a position is } \\
\text { commendable in the sense that a focus } \\
\text { on "simple pleasures" it is line with } \\
\text { sustainable development principles, } \\
\text { the passive nature of the choice means } \\
\text { that few people are affected or } \\
\text { encouraged to live in harmony } \\
\text { beyond the "garden walls". }\end{array}$ \\
\hline
\end{tabular}


Table 1. Cont.

\begin{tabular}{|c|c|c|c|}
\hline School/Perspective & $\begin{array}{c}\text { Type of } \\
\text { Wellbeing }\end{array}$ & Wellbeing Obtained Through & $\begin{array}{l}\text { Insight Stoicism Provides to Their } \\
\text { View on Sustainable Wellbeing }\end{array}$ \\
\hline $\begin{array}{l}\text { Peripatetics } \\
\text { (Aristotle) }\end{array}$ & Eudaimonic & $\begin{array}{l}\quad \text { Virtue as a necessary but not } \\
\text { sufficient component for the } \\
\text { eudaimonic life. One must also be } \\
\text { well-educated, possess wealth, } \\
\text { health, and even be reasonably } \\
\text { good looking to pursue the } \\
\text { excellence required to attain } \\
\text { eudaimonia. Women and male } \\
\text { members outside of elite circles } \\
\text { can never hope to } \\
\text { experience eudaimonia. }\end{array}$ & $\begin{array}{l}\text { Virtue, gained through } \\
\text { knowledge, is a key component for } \\
\text { the attainment of sustainable ideals. } \\
\text { That said, not only the elite should or } \\
\text { could be involved in the building of a } \\
\text { virtuous society and progress towards } \\
\text { societal wellbeing and sustainable } \\
\text { development. Anyone and everyone, } \\
\text { committed to acting more virtuously } \\
\text { can play a part in bringing sustainable } \\
\text { policy and practice into fruition. } \\
\text { In fact, they have a moral obligation } \\
\text { to do so. }\end{array}$ \\
\hline
\end{tabular}

Virtue, as the only necessary, sufficient and guaranteed means by which to experience eudaimonia. The ability to obtain virtue is open to everyone. Market goods, health, social position and educational attainment are at best preferred indifferents, which may indirectly support one's ability to execute virtue but can never directly lead to it or indeed sustain it. In other scenarios, these same conditions may have a neutral or negative impact on one's ability to be eudaimonic, which is why virtue, in and of its own right, is to be valued and pursued above all else.

\section{An individual's capacity to} live a "good life", through the opportunities freely provided to them. Personal freedom to positively choose one's lifestyle and preferences is an integral part to achieving eudaimonia, which is a preferred state but not necessarily the end goal of social agents. Capabilities are not the same as virtues and eudaimonia cannot be ascribed a singular as each individual's wellbeing is defined by them alone, based on their aspirations and preferences. Social status, including gender, can inhibit or enhance an individual's access to opportunities and capacity to express themselves.
The Roman Stoics, readily applied to personal ethics and wellbeing. However, Zeno's Republic of Sages (his ideal Stoic city) demonstrates a more collective vision of eudaimonia. It had "Communistic" elements, derived from his philosophical stance of belonging to the community as a whole and the moral obligation one has within it to behave virtuously.
Sen and Nussbaum Eudaimonic that there is a framework, and even a moral case, for students of the philosophy to offer insights into why a Stoic take on eudaimonia would, on offering an alternative to Sen, result in greater harmony in terms of societal wellbeing, sustainable development and appropriate resource management. 


\section{Stoicism, Sustainability and the Status Quo}

\subsection{Status Quo}

The near-universal acceptance of money and the capitalistic/consumerist ideal is something that Harari [3] argues most individuals (unfortunately) live up to, perhaps more so than their religious, spiritual or philosophical beliefs. In fact, the authority given to "market forces" as a sovereign leader of the Earth, rather than a subject reined in by its physical limitations, bears an uncanny resemblance to the god Spinoza describes in Ethics [4] to the point of being able to cite it near word for word:

"(Money is to be), endowed with human freedom, to take care of all things for men, make all things for their use and direct all things for the use of men in order to bind men and be held by men in the highest honour."

The license given to money and consequently economic growth is ubiquitous even in the most unlikely of places, should one accept that growth, by definition, cannot be sustained. This bias towards growth is evidenced in the United Nation's Sustainable Development Goals declaration [5], where the word is mentioned somewhat contradictorily (sustained growth, being sustainable) 17 times. This occurs, despite the evident presence of key aspects of eudaimonia in the premise and attainment of the Sustainable Development Goals (SDGs), as identified by Lamb and Steinberger (2017). The following is just one example:

\section{Sustained, inclusive and sustainable economic growth is essential for prosperity (Point 27).}

The SDGs growth rhetoric unfortunately goes unnoticed, even in the most socially aware circles (one would at least hope). In doing so, it crowds out environmental goals, which are already less in number, loosely defined and, more often than not, attended to as secondary concerns under a socio-economic banner [46]. Indeed, this position seems to be the antithesis of the United Nation's long-held objective of "reversing the depletion of environmental resources" or reducing the degree of climate change. A one percent growth in GDP leads to a 0.6 percent increase in material consumption, until stabilising at an unsustainable figure of approximately 20 tonnes/capita/year upon achieving a high Human Development Index [47]. Likewise, this same level of economic growth correlates to a 0.5 to 0.7 percent rise in carbon emissions [48,49].

Predictably, given the prevalence of GDP as a measure of wellbeing, it is hard to see growth for what it is. It is even harder to argue against its necessity, beyond the meeting of basic needs. Those who question the validity of the growth hypothesis are ignored, downplayed or said to engage in wishful "pre-industrialised" thinking.

The axioms that "all growth is good" and "a high rate of growth is better" is also drawn into the economic models that dominate public opinion and policy. For example, the environmental Kuznet's curve (named after the economist who designed GDP as a metric, but who warned against using it as a measure of wellbeing), is founded on the premise that progress, at least in the beginning, must occur at the expense of the environment [50]. It is thus of little wonder that mainstream economists fail to see the absurdity and impossibility of limitless growth and politicians advocate it as a preference, if not an absolute that cannot be argued against.

The incongruity of the aforementioned beliefs has not gone completely unnoticed and there have been various calls to re-design the economic system and the university curriculums of Economics classes, to reflect physical limits and planetary boundaries [50]. These are very welcome and important endeavours, but they must also be met with alternatives to neoclassical economics and non-economic theories, such as edgrowth, that are robust enough to tackle the ethical challenges and philosophical tensions that occur when there are inevitable disagreements as to what ought to be produced and why, and how the economy ought to serve society, instead of the other way around [50-52]. This involves putting Economics, via legal frameworks and collective decision making, in its rightful place as an integral, but not central, component of sustainable development. 


\subsection{Stoic Considerations for Sustainability: Virtue and Physics}

It is difficult to conceive an ideology further away from Stoicism than the aforementioned status quo. For a Stoic, it is not growth but virtue that supersedes all other considerations in societal progress towards eudaimonia, which does not in any case merely, or even necessarily, equate to a pleasant life. And, it is virtue, not money, that is the ultimate source of a life worth living.

One can even argue that a student of Stoicism - a prokopton (he/she that makes progress towards virtue) is under the moral obligation to challenge the neoclassical economic view of preferences. This is because the underlying assumption that utility is gained when $x$ and/or $y$ is added to one's possession is contrary to its fundamental tenets. In fact, at best, $x$ and $y$ if not virtues are preferred indifferents, as long as owning them does not run contrary to virtuous activity and (perhaps) moves one closer to what is appropriate to the natural human condition (Figure 1).

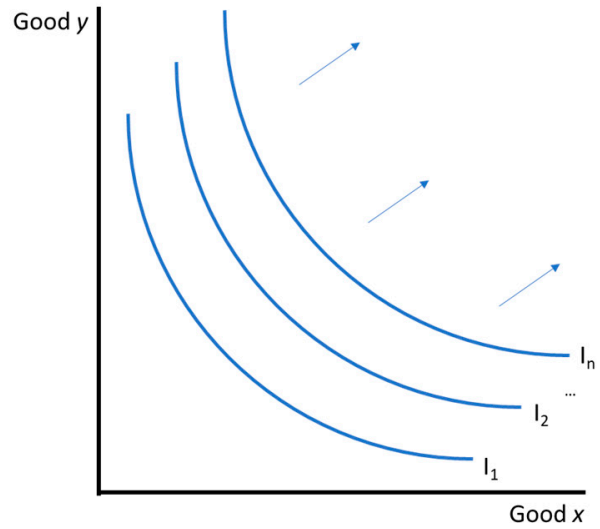

(a)

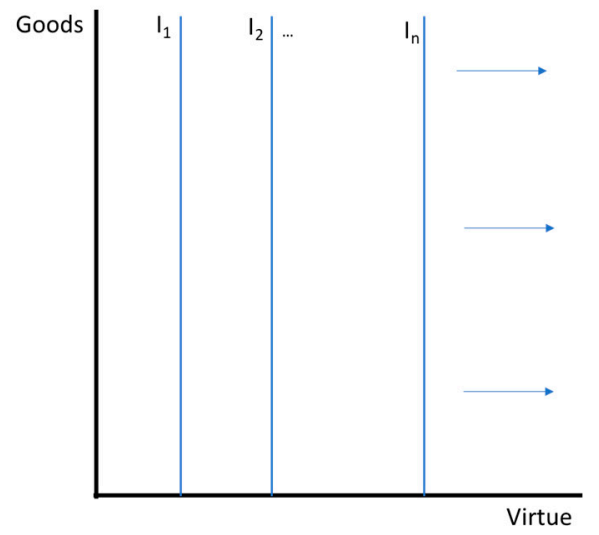

(b)

Figure 1. Indifference curves (a) Hedonic (neoclassical) value system; (b) Stoic eudaimonic value system whereby progress towards virtue is always preferred.

Consequently, a Stoic would be unlikely to profess a desire to have more or less material goods or for having them at all, as happiness cannot be obtained through anything except virtue. All externals are simply selections, which do not truly improve one's condition, and may actually serve to distract an individual from acting virtuously. In fact, it could be that $x$ and $y$ actively undermine one's virtue because in purchasing them, one inevitably supports and sustains the ways and means that created them: questionable sweatshop industries in Bangladesh, electronic factories in China, rainforest destruction in South America or shady financial agreements in the capital cities of Western Europe and North America.

The underlying concept was explored by Cicero who incorporated some Stoic aspects (and openly criticised others) in De Finibus (3.22) where he used the analogy of the archer or spear-thrower and the target (translation from Sellars [53]):

"One's ultimate aim is to do all in one's power to shoot straight, and the same applies with our ultimate goal ... To actually hit the target is, as we say, to be selected but not sought."

At the same time, Stoicism does not call for an abandonment of Capitalism or refrain from consuming in a way that Diogenes of Sinope would approve. Rather, and as Massimo Pigliucci states [33]:

"Stoicism is about developing the tools to deal as effectively as humanly possible, with the ensuing conflicts, it does not demand perfection and does not provide specific answers: those are for fools, who think the world is black and white, good versus evil, where it is always possible to clearly tell the good guys from the bad guys. That is not the world we live in, and to pretend otherwise is more than a bit dangerous and not at all wise". 
So, if Stoics are not charged with offering a specific solution, how can their philosophy contribute to the sustainable development discourse? Apart from actively progressing towards virtue, a practice that certainly does not preclude a person from making difficult and somewhat inconvenient choices, a student of Stoicism is also called to "follow nature" or to study "physics". To paraphrase Becker [54], they are obliged to investigate the nature of reality and those facts that determine an individual's physical existence and mental representation of the world.

In our opinion, and in line with a Stoic worldview, understanding physics starts with recognising that infinite growth can never occur because the first and second law of thermodynamics establish the realm of that impossibility, regardless of technological efficiencies. The second law requires that where there is creation in entropy there is an un-negotiable change in the universe. It thus bestows society with a non-arbitrary sense of economic value. It asserts that in every irreversible transaction, such as digging for precious metals or polluting the oceans, quality (exergy) is destroyed and that it is destroyed forever [55]. It provides irrefutable evidence that the energy and material demand of most developed (and a few developing) world citizens is not sustainable and has led to the transgressing of planetary boundaries [56].

Part of "following nature" and studying "physics" is recognising that human life, despite our anthropocentric paradigm, is an integral part of Nature and that the short term economic attitude prevalent in both public and private sector decision making is at odds with longer term natural cycles. Perversely, our wastes are much more long term than the shorter "waste" cycles of Nature, something which also affects the balance.

Understanding the reality of physical limits is accepting both the nature of the universe and the nature of our current situation within it. In terms of the former consideration, advances in astrophysics and space exploration have shown that whilst the universe is expanding, the number of planets that are both the right size and composition, and which occupy an appropriate distance from an appropriately sized and type of star, are few and far between. The "Goldilocks conditions" are rare and even with the right technology there are no guarantees. Consequently, and although the optimist can point to the theoretical reality of being able to colonise elsewhere, our physical limits have not changed and nor are they likely to for the foreseeable future. We inhabit a small planet and while we are able to print more money (making any obsession with it outrageous), we cannot create more space. Of course, techno-optimists having effectively silenced Malthus' [57] alarmist projections will highlight humankind's ability to conquer Nature's limits. Yet, what they are actually demonstrating is humanity's power to re-shape Nature, to squash her, in order to make, not more space per se but more space for us. That aside, population size is not the real issue. The problem is the demand for growth, which relies on and is supported by finite resources. In turn, the exploitation of land frequently encroaches upon non-Westernised communities and an animal's or plant's capacity to co-exist.

\subsection{Stoic Considerations for Sustainability: Circles of Concern and Oikeiôsis}

A key Stoic understanding of co-existence is derived from and clearly demonstrated through Hierocles' circles and the Stoic concept of oikeiosis. The latter term is most readily translated as "appropriation," "orientation," "familiarisation," or "affinity" and is the first impulse felt by an animal or plant. It is made manifest by the innate drive for self-preservation (rather than pleasure as an Epicurean worldview would uphold). In a mammalian infant, it shows itself in the need to draw from the mother's milk and in the seeking of her for nutrition, affection and protection, all of which enhance survival and are in themselves an act of self-love. As a human child matures, their sense of self is transformed by rationalisation, a process which Stoics argue leads to an affinity towards Nature and a recognition that self-preservation is an appropriate disposition. Consequently, how one interacts with, and relates to, the external environment requires deliberation and corrective action (in other words, the execution of virtue) to bring about the best possible state $[29,58]$.

Despite appearances, the "best possible state" does not need to take on the Utilitarian notion of the greatest good for the greatest number. Rather, it reflects the Stoic thought that one should be selfish 
through selflessness. That is, if something is in the interest of the whole of humanity, not just most, and not just one's family, or tribe, or society, then and only then, it is of interest to the individual [59]. Consequently, those tuned into this reality are closer to wisdom, self-control and justice. They are, according to Stoic ontology, acting appropriately towards their fellow kin.

Metaphysical considerations aside, such notions challenge consumerism and mainstream economic thought, particularly hedonic interpretations of satisfaction, at a number of levels. Under Stoicism, the acquisition of goods and services is not only a preferred indifferent but also carries a moral component, in that one's preferences, if they do not benefit the whole, do not and cannot maximise utility for the consumer. This is particularly true, as its runs contrary to a Stoic's perception of nature, if consumption forms part or a zero sum game or, as Lamb and Steinberger [60] observe, a competitive means to acquire social status through the possession of "scarce" or "desirable" goods.

Such competitive economic mechanisms create scenarios that play out into match ups of "personal gain" vs. "planetary duty", and "long term benefits for future generations" vs. "the here and now". Yet, and as Gill $[17,61]$ argues, these are false dichotomies that can be overcome if one frames the dilemma in terms of an extended Stoic idea of virtue and eudaimonia. Virtuous action and the ability to flourish do not just involve human to human relations, but instead encompass all human relationships, including those one has with other living beings and the Earth itself. Consequently:

\begin{abstract}
"If we accept that virtuous action includes acting in an environmentally responsible way, we will come to see such action as contributing to our happiness and the best human life. We will not see our situation as one in which we are forced to choose between acting in a way that promotes our own happiness and acting in a way that minimises harm to the environment or which benefits future generations ..." -Gill [61]
\end{abstract}

Stoicism thus directly juxtaposes Bentham's utilitarian ideas of maximising individual "happiness" by supplying products and services with which to fill a perceived malaise. For a follower of Stoic philosophy, any discontent arises from the internal struggle created by unfounded or poor/mistaken value judgements (false impressions), which in turn lead to, and are responsible for, negative emotions [19]. Such feelings can then be remedied by returning to one's true nature, expressed through virtue and understood through shared kinship.

The Stoic vision of kinship remains, even in the 21st century, a progressive one. Modelled on Hierocles' circles, the idea is to begin with the recognition of the self and then spread out to concentric circles lying further out and bring them back onto oneself. In repeating this exercise, the Stoic recognises the whole of humanity in themselves and vice versa. Beyond that, which is explained in Section 2, the concept takes on special significance when one considers the expansion of the world map and the new scientific discoveries, including Darwin's evolution, that have occurred, since the early Stoics first came up with the idea of cosmopolitanism. The biological similarity between all life on Earth, whilst not able to explain all the nuances that exist between and within species, is indicative of common ancestry and kinship ties. This is clearly seen in the difference between human and chimpanzee DNA, for example, which is only four percent, once insertions and deletions have been accounted for [62]. It is also evidenced by the fact that in some sequences of the genome, the similarity between that of bonobos and humans or chimpanzees and humans is higher than it is between chimpanzees and bonobos [63]. It is, in turn, this modern understanding, in addition to our increased knowledge of bio-chemical and bio-physical processes and the widespread recognition of global environmental challenges that, according to Konstantakos [29], "would have been enough for Hierocles to add a few more circles to his model, had he known about them."

For this reason, we propose the expansion of Hierocles' model of concern to include non-human aspects, as shown in Figure 2. In light of the serious talks and working groups proposing that the current geological epoch is no longer the Holocene but rather the Anthropocene [64], we think that there are also reasonable grounds to include temporal and not just socio-geographical kinship ties, as was first envisioned. Arguably the question is where, and not if, one should place future generations 
on this scheme. One may also suggest that "community" should be sub-divided within the concentric ring to reflect the complexity of the 21st century and its social networks. Also, and whilst it is beyond the scope of this paper, is there really one society instead of societies? Indigenous communities, for example, do not actively participate in, nor necessarily agree with Western norms. Where should such communities be placed in Figure 2? After all, it is the westernised demand for hedonic satisfaction, material consumption and economic growth which opens up mines and oil fields in their territories.

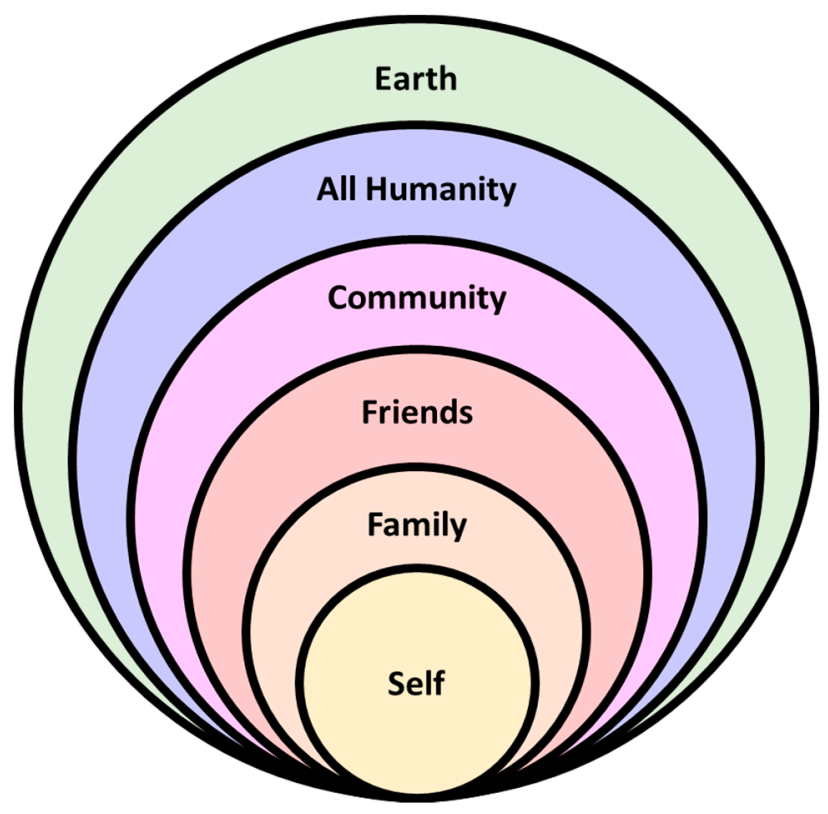

Figure 2. A 21st century adaption of Hierocles' model of concern. At the very centre of the self is the mind. A Stoic takes care of the body for the sake of the mind and from there branches out.

\subsection{Stoic Considerations for Sustainability: The Sage}

The Sage is the central figure in Stoic philosophy and is the character all prokoptons ought to aspire to be. They are not perfect, in the absolute sense of the word, as they do not possess the qualities of omniscience or omnipotence, as ascribed to the Abrahamic God. Their decisions are correct in the sense that they are perfectly moral given the knowledge they can reasonably be expected to have at that precise moment. They do the right thing and they do all the right things for the right reasons [65].

Consequently, Sages are representative of a person who is living, as far as is humanly possible, as evidenced through their acts, the four cardinal virtues recorded in Plato's Republic (427e-435c, 441c-443c), and integrated into Stoicism via Zeno and his successor Cleanthes [66]. They are not, therefore, typical exemplars falling under the bell-shaped curve. Yet, they have experienced directly or, as in the case of extremes (e.g., murder, suicide), are sufficiently acquainted with the widest possible range of both favourable and unfavourable circumstances and conditions faced by humankind.

So, what does modern society require from their Sage? Specialisation is the order of the day and whilst one multi-skilled physician would have sufficed (and indeed been very welcome) in the Classical Greece or Ancient Rome inhabited by Stoics of the past, the same cannot be said for the modern practice of medicine, as Atul Gawande testifies [67]. This goes to show that in the 21st century, and particularly when it comes to the nature and complexity of modern society, no one Sage can know all there is to know about each and every conceivable aspect that must be considered to make appropriately wise decisions. Sustainable development, which has an even wider scope than the one health care practitioners are charged with, provides a particularly notorious case as to the need for collective action (and not just the forming of views) taken by multidisciplinary teams to mitigate unacceptably high and altogether uncertain risks [68]. 
Described in Stoic terms, a number of virtuous agents (Sages), not just the odd few, will need to come together from a wide range of disciplines (e.g., the climate, environmental, material, political and social sciences, economics, philosophy), occupations (CEO, journalists, politicians, schoolteachers) and walks of life to safely guide the rest of humanity on a coherent course of sustainable development. This is because, other than an individual's primary role to act as a rational person, sustainability has its nuances and should be, under a Stoic framework, approached differently by individuals occupying different roles. Any sustainable consensus would be in the nominal sense, in that "being sustainable" does not come down to a legally or politically binding set of ascribed deeds, but rather an impression of what is good, to know that it is in fact good and the ability to act accordingly. Lastly, it is worth stating that a society founded on Stoic principles and focused on virtue and eudaimonia would not be free from relentless trials and tribulations.

Arguably, sustainable development represents an ideal state where the needs of the present are perfectly balanced with those of the potentially unknowable needs of future generations. Further, and if its holistic depiction symbolises eudaimonia, as Brand-Correa and Steinberger [69] and Lamb and Steinberger [60] testify, then like virtue (in the singular) it is something to keep in the mind's eye and actively progress towards, without the promise that it will ever be fully realised.

This is especially true as science steadily uncovers the existing gaps of knowledge that underlie the physical reality of the universe, including the nature of those that occupy it. In which case, and accepting the logical Stoic conclusion, society, save for a few Sages, will be just as vicious [70]. As absurd as the latter may sound, the notion that those living now can, and thus should always, do more, for those who will inherit the Earth tomorrow, is not an unreasonable proposition, and consequently, neither is the viewpoint that the failure to live up to this demand is unacceptable, vicious.

Having said that, progress is fundamental to Stoicism, hence the use of the Greek term, prokopton to describe a practitioner of the philosophy. As such, and despite the possibility of failure, one has a moral obligation to move towards virtue, in the same way that one has a moral obligation towards the future generation and their collective ability to live virtuously, even if nothing is guaranteed. No one, not even the Sage, can know for sure what the future holds. Yet, given the Stoic requirement to act prudently, which, as Robertson [71] states, requires deliberative excellence, quick-wittedness, good calculation, a good sense of purpose and resourcefulness, it is clear that a Sage will avoid unnecessary risks whilst acting or showing care and thought for the future. In short, they will be, by definition, living the concept of sustainable development first put forward by Brundtland [72]. They will achieve this through their ability to govern via reason, skill and good judgment when it comes to the use of natural resources.

\section{Stoicism and Material Services}

Access to and the quality of material services are two interconnected aspects indicative of societal progress towards sustainable development. Under a hedonic based economic system, the distribution of material resources has not only played an important role in wealth acquisition and accumulation [73] but has also historically been, and continues to be, linked to wellbeing, through the proxy of economic welfare and its associated indicators, including GDP per capita [69]. These concepts, in turn, derive from the Utilitarian notion that happiness can be maximised with material goods and services. It is this paradigm, along with that of infinite growth via capital accumulation, that provides the rationale behind the continual drives for mass resource extraction, production, consumption and disposal [74]. Consequently, reducing consumption does not only concern environmental limits but also plays on the public psyche, as any policies that do not encourage growth are perceived to be an attack on our way of life, precisely because they present a threat to the possibility of increasing public and personal wellbeing. Yet, as Carmona et al. [3] contest, a consumer does not actually want, or indeed require, material $x$ nor $y$, but rather the service which either (or both) materials provide. In which case, it is the 
material services, rather than the material products, that the economic system ought to be designed to deliver [75]. Whereby a material service constitutes [3]:

"Those benefits that materials contribute to societal wellbeing, through fuels and products (regardless of whether or not they are supplied by the market) when they are put to proper use".

As humankind has developed into more advanced civilisations, it has come to rely on 14 material services, which are inherently linked to what Doyal and Gough [76] call human needs (Figure 3). All 14, originally defined by Carmona et al. [3], were experienced by Stoics in Classical Greece and Ancient Rome. Furthermore, whilst modernity has improved the quality of those services, the nature of them and the benefits they provide would be recognisable to the Ancient populations of Greek and Roman cities. They are thus universal to the human experience across both spatial and temporal aspects.
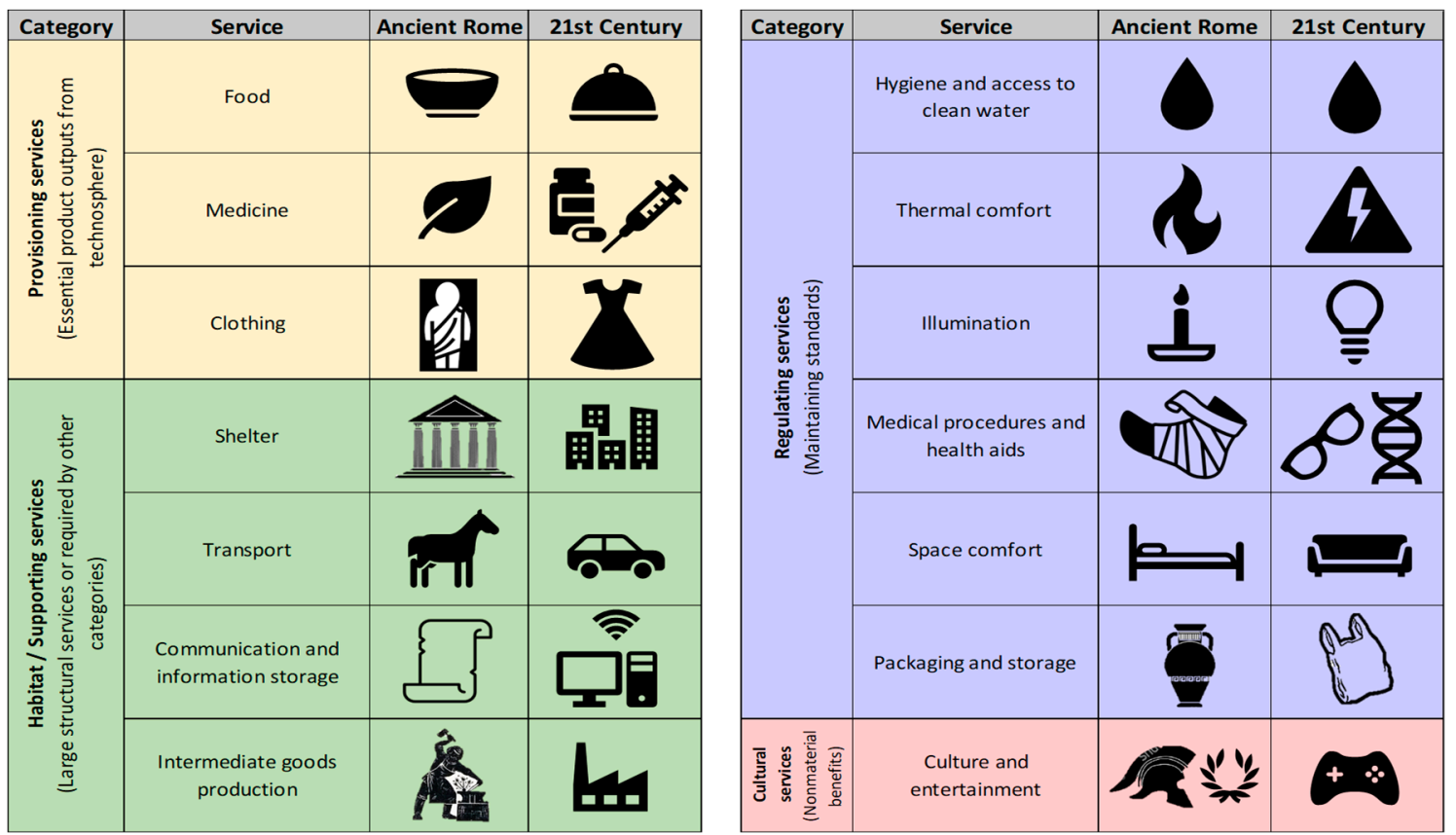

Figure 3. The universality of material services through time.

Considering the importance and universality of material services, the focus of the economic system, given the finite nature of Earth's resources, should therefore ensure the proper, efficient and effective distribution of material services, not materials per se. This is because it is the ability to access and be supported by such services that, and to use Stoic terminology, enables an individual to live in a virtuous society. The latter is taken to be one that values and seeks out prudence, courage, self-control and justice. Active members of such a society would agree that it is the obtaining of all these virtues that produces fulfilment and leads to flourishing, and is thus the only thing for the sake of which everything else is done [54].

But how does such a state play out in reality, which indeed it must, given the Stoic axiom that something may not truly exist without action? Under a Stoic framework, market forces only serve hedonistic claims to wellbeing, which may act as a distraction by merely providing a flood of potential selections from which to choose from. These, by definition, have no bearing on virtue, nor can truly be considered preferences. Likewise, neither material consumption nor material efficiency can be used as metrics to identify what natural resources are destined for or if their production promotes eudaimonic wellbeing. For the Stoic, all actions must reiterate the preference of virtue, as the only good worth seeking and reaching for. They must also shed light on the moral obligation one has not to hinder, but to actively aid, an individual in advancing their capacity, or ability, to strive towards virtue, alongside an understanding that what is good for the whole is good for the self. 
Most sustainability discussions in modern Stoic circles emphasise the individual's duty towards the environment, made manifest by living moderately and reining in consumerist appetites. Such behaviours are, of course, entirely consistent with sustainable development, but are more introspective and passive in nature; a means of exercising self-control and an opportunity to re-focus on the non-material aspects of self-development [77]. Such a stance says nothing about material services and wider resource policy, although it does address the need to deal with the material footprint. Material stock increased 23-fold from 1900 to 2010, whilst the amount of raw materials used to create or renew stocks rose from $1 \mathrm{Gt} /$ year to $36 \mathrm{Gt} /$ year [78]. This reflects the substantial effort and resources society expends to build, enhance and maintain its material wealth. These figures lend support to Kahneman et al. [79]'s microeconomic behavioural study on endowment effect and loss aversion. They demonstrate that what has been found on the micro level also occurs at the macro. Given this reality, one can argue that a Stoic perspective on the temporary nature of things is helpful to re-address the balance:

With regard to whatever objects give you delight, are useful, or are deeply loved, remember to tell yourself of what general nature they are. If you have a favourite cup or mug, say that it is not your favourite, then when it breaks you won't be disturbed. -Epictetus, The Enchiridion, Chapter $3[80,81]$

Epictetus' observation on consumerism in second century Rome is not the only evidence indicative of the fact that the SPQR (the Ancient Roman Republic) was more modern and consumerist, even outside elite circles, than one might think. Indeed, well into the 21st century there are some members of humankind still living under the shadow of extreme poverty and who have less access to food than the slaves living in Ancient Rome and the pre-Vesuvius eruption Bay of Naples [82]. This is evidenced by the fact that none of the skeletons examined at Herculaneum showed signs of malnutrition, and on the contrary, enjoyed a more varied diet than their modern Neapolitan counterparts [83]. Likewise, the average height of both men $(163.83 \mathrm{~cm})$ and women $(153.67 \mathrm{~cm})$ of Ancient Herculaneum indicate a reasonable level of health. The Roman capital also ensured that its citizens had access to staples. Some of the poorest received a rationed grain supply free of charge [84]. On comparing both skeletal remains and Ancient Roman food policy to the $22.9 \%$ of children under five years old who experienced stunted growth between 2010 and 2016 [85], it becomes evident that hedonic value systems, whilst creating more material and financial wealth have not equalised distribution, even for the most basic of provisioning services-food. The same can be said for access to water and hygiene (sewers). Herculaneum had a primary and secondary sewage system, three public baths and 80 latrines [82]. Lead pipes provided clean running water directly into individual middle class homes throughout the Roman Empire including in Rome, Pompeii and Herculaneum [86]. In Rome, even the most conservative estimates of 520,000-635,000 cubic metres of clean water provision per day for a population of one million, where 44 per cent went to the public [87], means that at least 208 litres were provided per capita/per day. This figure is higher than the water supply volume ranges of 50 to 150 cubic metres per capita/per day in EU member states, although water quality has certainly improved [88]. Such statistics indicate better service access and quality in richer parts of the globe, but certainly not the poorest, where less than half of the population enjoys access to clean water [89].

Other material services experienced en masse in the 21st century West are remarkably recognisable to Ancient Rome's inhabitants. The Roman elite enjoyed an early form of private central heating, a service also accessed by the middle and lower classes in the public baths [90]. The throwaway culture often associated with modern consumerism was also present in second and third century Rome, as demonstrated by the disposal of 40 to 53 million clay amphorae (that could only be used once, as the remnants of oil they contained prevented any re-use) at the Monte Testaccio "landfill" [91,92]. Furthermore, it would take well into the Industrial Revolution (if not beyond it) before Ancient Rome's level of material services, in terms of distribution and quality, could be matched [92]. This fact testifies to the applicability of Stoic thought when it comes to how materials could be used to support sustainable development through Stoic virtue and eudaimonia, as proposed in Figure 4. 


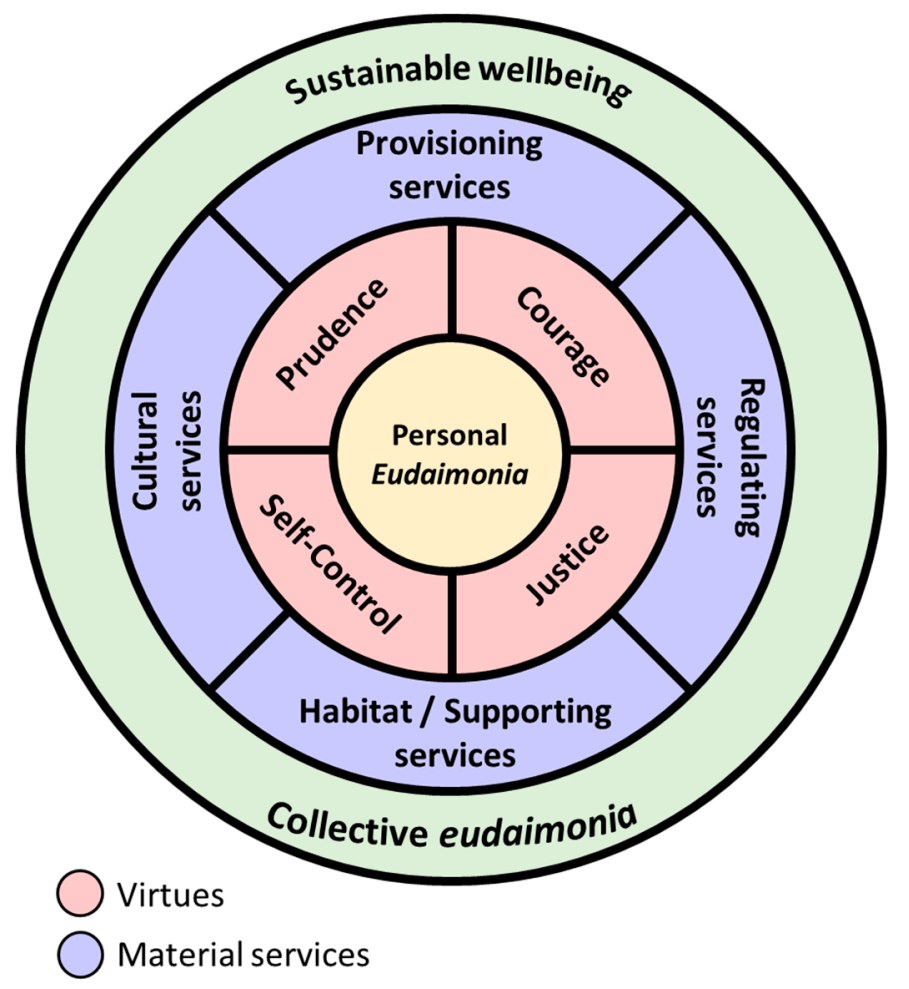

Figure 4. Sustainable wellbeing achieved through a Stoic framework.

Personal wellbeing placed at the centre point of Figure 4, reflects the Stoic target of experiencing eudaimonia, achieved by acting justly, courageously with prudence and self-control. Leaders in the early Stoa of Classical Greece were also concerned with a collective view of a virtuous society, which is why we feel that the concept presented does not detract from Stoic values. As attested to previously, for both modern society and Ancient civilisations, collective wellbeing (both hedonic and eudaimonic) is and was supported by material services. Arguably, for a Stoic, it is the access to and the quality of material services which support sustainable wellbeing, because, although they are not sufficient in and of their own right, they do enable the individual and the collective to act virtuously, both in the present and the future.

Although the virtue of self-control is the one most directly associated with materialism, it is only one element of virtue (in the singular) and unless all virtues are met, none are truly met, and the Stoic take on eudaimonia ceases to exist [54]. Thus, Stoicism, when applied to sustainability goes further than practicing Epictetus' un-attachment and self-control when choosing to produce or replace things should they break (or die). It does however call people to act differently, in the sense that although the level of commitment to sustainable development should be the same, one should not expect the poorest crippled slave (Epictetus) to demonstrate his adherence to its principles in the same way as the world's elite (Marcus Aurelius). Another key point to highlight is Zeno's Republic and the strong undertones of what one would call "Communism" in modernity. One of the aspects that derives from his philosophical stance of the ideal Stoic city, is the communal sense of membership, bound by moral obligation to each other. There is even mention of unisex clothing to fulfil the material service rather than hedonic aspirations, given that for Stoics, there is no need to look attractive or stand out in terms of status (gender, then as now, remains linked to societal position), as it has no bearing on one's ability to act virtuously. For Zeno, the sharing of all property and relationships was an integral element of a virtuous society [93]. This stance, as extreme now as when it was originally conceived, is again indicative of the Stoic goal to advance common good through virtue, which does not require ownership nor wealth accumulation to be achieved. Arguably, an updated rendition of this thought 
process can be seen in the proliferation of the membership economy, as a means to enhance the quality of material services, whilst also supporting sustainable development [3]. For Stoics, whilst one does not need to be wealthy or educated in order to be moral, if one happens to be healthy, educated, and so forth, this is good and in fact facilitates one's practice of the virtues, because a wealthy and educated person can do much good in the world [94]. Whilst education is not a material service it is supported by other ones.

Currently, Stoicism does not have much to say on collective virtue and how it might be achieved. Gough's [95] exploration of human needs theory (with his emphasis on function rather than feelings) may provide insights as to how Stoic philosophy could incorporate the effect of basic material preconditions and their impact on societal progress towards virtue.

On a practical note then, it raises the question of how much material is needed to support virtue and how best to measure the collective advancement towards it, using access to and the quality of material services as a proxy. Such a question cannot, unfortunately, be answered within the scope of the present paper, but is something that must be considered if Stoicism is to become an active philosophy in the sustainability debate.

\section{Conclusions}

Stoicism requires its students (and its Sages) to deliberate on the role of materials, with regards to how their mining, production, use and disposal shapes the world and its processes. It requires them to examine the nature of those preferences, both personal and societal, which lead to the existence of material goods and their environmental impacts.

A Stoic must conclude that material production and consumption must serve the purpose of facilitating collective virtue, in the sense that materials should be used in a way that enables more people to obtain wisdom through greater access to material services. Just distribution of the latter should be prioritised given that true wellbeing (fulfilment) can only be achieved by maximising virtue, rather than any hedonic notions of happiness. Our paper has demonstrated that Stoic principles can be applied successfully to sustainable development, although more work into collective progress towards virtue needs to be undertaken. It establishes that there is merit in the Stoic underlying assumption that sustainable development can only be achieved as a product of the relentless pursuit for good; the sustenance of Stoic virtue, from which, and only which eudaimonia can emerge. Accordingly, and having shown the applicability of Stoicism to the modern problem of sustainability, the challenge for practitioners (advocates) of the philosophy is to make the case for and demonstrate the reality of Stoic eudaimonia, as the only real state that can put a halt to requests for something better, and which does not require limitless growth to be achieved.

Acknowledgments: Kai Whiting and Luis Gabriel Carmona acknowledge the financial support of Fundação para a Ciência e a Tecnologia (FCT) and MIT Portugal Program through the grants PD/BP/113742/2015 and PD/BD/128038/2016; MARETEC acknowledges the support of FCT/MCTES (PIDDAC) through project UID/EEA/50009/2013. We thank Chris Gill for his helpful comments, suggestions and advice. We also thank him for access to his unpublished material. We also appreciate the time taken by Hanna Murray-Carlsson, Tânia Sousa and Gonçalo Marques to comment on this paper.

Author Contributions: Kai Whiting conceived this study, led the narrative framing for the paper and coordinated its writing. Kai Whiting, Leonidas Konstantakos and Luis Gabriel Carmona focused on the Stoic principles applied to a historic and modern context. Leonidas Konstantakos provided insights into Greek terminology. Kai Whiting, Luis Gabriel Carmona and Angeles Carrasco integrated the concept of Stoicism with material services.

Conflicts of Interest: The authors declare no conflict of interest.

\section{References}

1. Schandl, H.; Fischer-Kowalski, M.; West, J.; Giljum, S.; Dittrich, M.; Eisenmenger, N.; Geschke, A.; Lieber, M.; Wieland, H.P.; Schaffartzik, A. Global Material Flows and Resource Productivity; Assessment Report for the UNEP International Resource Panel; United Nations Environment Programme: Paris, France, 2016. 
2. National Research Council. Science for Environmental Protection: The Road Ahead; National Academies Press: Washington, DC, USA, 2012; ISBN 0-309-26490-1.

3. Carmona, L.G.; Whiting, K.; Carrasco, A.; Sousa, T.; Domingos, T. Material Services with Both Eyes Wide Open. Sustainability 2017, 9, 1508. [CrossRef]

4. Foster, J.B.; Burkett, P. Marx and the Earth: An Anti-Critique; Brill: Leiden, the Netherlands, 2016; ISBN 90-04-28879-1.

5. Cullen, J.M. Circular Economy: Theoretical Benchmark or Perpetual Motion Machine? J. Ind. Ecol. 2017, 21, 483-486. [CrossRef]

6. Ryan, R.M.; Deci, E.L. On happiness and human potentials: A review of research on hedonic and eudaimonic well-being. Annu. Rev. Psychol. 2001, 52, 141-166. [CrossRef] [PubMed]

7. Huta, V.; Ryan, R.M. Pursuing pleasure or virtue: The differential and overlapping well-being benefits of hedonic and eudaimonic motives. J. Happiness Stud. 2010, 11, 735-762. [CrossRef]

8. Harari, Y.N. Homo Deus: A Brief History of Tomorrow; Random House: New York, NY, USA, 2016; ISBN 1-4735-4537-4.

9. Lenin, V.I. Our foreign and domestic position and the tasks of the party. Collect. Works 1965, 31, 408-426.

10. Sellars, J. Which Stoicism? In Stoicism Today: Selected Writings; Ussher, P., Ed.; Stoicism Today: Exeter, UK, 2014; Volume 1, ISBN 1-5024-0192-4.

11. Pigliucci, M. Stoicism. Available online: http:/ /www.iep.utm.edu/stoicism/ (accessed on 11 November 2017).

12. Anscombe, G.E.M. Modern Moral Philosophy. Philosophy 1958, 33, 1-19. [CrossRef]

13. Robertson, D. The Philosophy of Cognitive-Behavioural Therapy (CBT): Stoic Philosophy as Rational and Cognitive Psychotherapy; Routledge: London, UK, 2010; ISBN 1-78049-280-4.

14. Irvine, W.B. A Guide to the Good Life: The Ancient Art of Stoic Joy; Oxford University Press: Oxford, UK, 2008; ISBN 0-19-979262-3.

15. Robertson, D. Stoicism and the Art of Happiness-Ancient Tips for Modern Challenges: Teach Yourself; Hachette UK: London, UK, 2013; ISBN 1-4441-8712-0.

16. Brown, D. Happy; Random House: New York, NY, USA, 2016; ISBN 0-593-07620-6.

17. Gill, C. Stoicism and the Environment. In Stoicism Today: Selected Writings; Ussher, P., Ed.; Stoicism Today: Exeter, UK, 2014; Volume 2, ISBN 1-5024-0192-4.

18. Gill, C. What is Stoic Virtue? In Stoicism Today: Selected Writings; Ussher, P., Ed.; Stoicism Today: Exeter, UK, 2014; Volume 2, ISBN 1-5024-0192-4.

19. Sellars, J. Stoicism Today: John Sellars on Stoicism and Emotions; Stoicism Today: Exeter, UK, 2015.

20. Annas, J. Seneca: Stoic Philosophy as a Guide to Living. In The Practice of Virtue: Classic and Contemporary Readings in Virtue Ethics; Hackett: Indianapolis, IN, USA, 2006; pp. 156-169.

21. Pigliucci, M. Why Virtue Is Sufficient for a Life Worth Living. Available online: https:/ /howtobeastoic. wordpress.com/2017/10/27/why-virtue-is-sufficient-for-a-life-worth-living/ (accessed on 30 January 2017).

22. Clark, S.J. How now, Horatio? The Stoic Joy of Nature and Friendship. In Stoicism Today: Selected Writings; Ussher, P., Ed.; Stoicism Today: Exeter, UK, 2014; Volume 2, ISBN 1-5024-0192-4.

23. Daw, M. On the Motivations of a Stoic. In Stoicism Today: Selected Writings; Ussher, P., Ed.; Stoicism Today: Exeter, UK, 2014; Volume 1, ISBN 1-5024-0192-4.

24. Ussher, P. The Stoics on the Community of Humankind. In Stoicism Today: Selected Writings; Ussher, P., Ed.; Stoicism Today: Exeter, UK, 2014; Volume 1, ISBN 1-5024-0192-4.

25. Long, A.A.; Sedley, D.N. The Hellenistic Philosophers: Volume 1, Translations of the Principal Sources with Philosophical Commentary; Cambridge University Press: Cambridge, UK, 1987; ISBN 1-139-64289-8.

26. Nussbaum, M. Patriotism and cosmopolitanism. In Twentieth Century Political Theory: A Reader; Bronner, S.E., Ed.; Psychology Press: Hove, UK, 2005; pp. 159-168, ISBN 0-415-94898-3.

27. Evans, J. The Stoic Mayor. In Stoicism Today: Selected Writings; Ussher, P., Ed.; Stoicism Today: Exeter, UK, 2014; Volume 1, ISBN 1-5024-0192-4.

28. Hadot, P. What Is Ancient Philosophy; Harvard University Press: Cambridge, MA, USA, 2004; ISBN 0-674-01373-5.

29. Konstantakos, L. Would a Stoic Save the Elephants? In Stoicism Today: Selected Writings; Ussher, P., Ed.; Stoicism Today: Exeter, UK, 2014; Volume 2, ISBN 1-5024-0192-4.

30. Van Natta, M. The Stoic Love of Community. In Stoicism Today: Selected Writings; Ussher, P., Ed.; Stoicism Today: Exeter, UK, 2014; Volume 1, ISBN 1-5024-0192-4. 
31. Oldfather, W. Epictetus, the Discourses as Reported by Arrian, the Manual and Fragments; Harvard University Press: Cambridge, MA, USA, 1925.

32. Gill, C. The Stoics on humans, animals and nature. (unpublished).

33. Pigliucci, M. How to Be a Stoic: Using Ancient Philosophy to Live a Modern Life; Hachette UK: London, UK, 2017; ISBN 0-465-09796-0.

34. Putnam, H.; Neiman, S.; Schloss, J.P. Understanding Moral Sentiments: Darwinian Perspectives; Transaction Publishers: Piscataway Township, NJ, USA, 2014; ISBN 1-4128-5444-X.

35. Fowers, B.J. Aristotle on eudaimonia: On the virtue of returning to the source. In Handbook of Eudaimonic Well-Being; Springer: Berlin, Germany, 2016; pp. 67-83.

36. Nussbaum, M.C. The Fragility of Goodness: Luck and Ethics in Greek Tragedy and Philosophy; Cambridge University Press: Cambridge, UK, 2001; ISBN 0-521-79472-2.

37. Evans, J. The End of History and the Invention of Happiness. In The Politics of Wellbeing: Theory, Policy and Practice; Palgrave Macmillan: Basingstoke, UK, 2017.

38. Pawelski, J.O.; Moores, D.J. The Eudaimonic Turn: Well-Being in Literary Studies; Fairleigh Dickinson: Teaneck, NJ, USA, 2012; ISBN 1-61147-529-5.

39. Mitsis, P. Epicurus: Freedom, Death, and Hedonism. In The Oxford Handbook of the History of Ethics; OUP Oxford: Oxford, UK, 2013; p. 73.

40. Nussbaum, M.C. The Therapy of Desire: Theory and Practice in Hellenistic Ethics; Princeton University Press: Princeton, NJ, USA, 2013; ISBN 1-4008-3194-6.

41. Sen, A. Well-being, agency and freedom: The Dewey lectures 1984. J. Philos. 1985, 82, 169-221. [CrossRef]

42. Sen, A.K. Well-being, capability and public policy. G. Degli Econ. E Ann. Econ. 1994, 333-347.

43. Sen, A. Commodities and Capabilities; Oxford University Press: Oxford, UK, 1999.

44. Ransome, B. Sen and Aristotle on wellbeing. Aust. J. Soc. Issues 2010, 45, 41-52. [CrossRef]

45. Nussbaum, M. Capabilities as fundamental entitlements: Sen and social justice. Fem. Econ. 2003, 9, 33-59. [CrossRef]

46. Raworth, K. Will these Sustainable Development Goals Get us into the Doughnut? In From Poverty to Power: How Active Citizens and Effective States Can Change the World; Green, D., Ed.; Oxfam: Oxford, UK, 2012; ISBN 1-85339-741-5.

47. Schandl, H.; Fischer-Kowalski, M.; West, J.; Giljum, S.; Dittrich, M.; Eisenmenger, N.; Geschke, A.; Lieber, M.; Wieland, H.; Schaffartzik, A. Global Material Flows and Resource Productivity: Forty Years of Evidence. J. Ind. Ecol. 2017. [CrossRef]

48. Wiedmann, T.O.; Schandl, H.; Lenzen, M.; Moran, D.; Suh, S.; West, J.; Kanemoto, K. The material footprint of nations. Proc. Natl. Acad. Sci. USA 2015, 112, 6271-6276. [CrossRef] [PubMed]

49. Burke, P.J.; Shahiduzzaman, M.; Stern, D.I. Carbon dioxide emissions in the short run: The rate and sources of economic growth matter. Glob. Environ. Chang. 2015, 33, 109-121. [CrossRef]

50. Raworth, K. Doughnut Economics: Seven Ways to Think Like a 21st-Century Economist; Chelsea Green Publishing: White River Junction, VT, USA, 2017; ISBN 1-60358-674-1.

51. Kallis, G.; Kerschner, C.; Martinez-Alier, J. The economics of degrowth. Ecol. Econ. 2012, 84, $172-180$. [CrossRef]

52. Martínez-Alier, J.; Pascual, U.; Vivien, F.-D.; Zaccai, E. Sustainable de-growth: Mapping the context, criticisms and future prospects of an emergent paradigm. Ecol. Econ. 2010, 69, 1741-1747. [CrossRef]

53. Sellars, J. Stoicism and the Art of Archery. Available online: http://modernstoicism.com/stoicism-and-theart-of-archery / (accessed on 11 November 2017).

54. Becker, L.C. A New Stoicism; Princeton University Press: Princeton, NJ, USA, 2017; ISBN 1-4008-8838-7.

55. Georgescu-Roegen, N. The Law of Entropy and the Economic Process; Harvard University Press: Cambridge, MA, USA, 1971.

56. Steffen, W.; Richardson, K.; Rockström, J.; Cornell, S.E.; Fetzer, I.; Bennett, E.M.; Biggs, R.; Carpenter, S.R.; de Vries, W.; de Wit, C.A. Planetary boundaries: Guiding human development on a changing planet. Science 2015, 347, 1259855. [CrossRef] [PubMed]

57. Malthus, T.R. An Essay on the Principle of Population: Or, a View of Its Past and Present Effects on Human Happiness; Reeves \& Turner: London, UK, 1888.

58. William, O. Stephens Stoic Ethics. Available online: http://www.iep.utm.edu/stoiceth/\#H2 (accessed on 11 November 2017). 
59. Glassborow, N. “Without the Divine, There Is No Stoicism”: A Polemic. Available online: http:/ / modernstoicism. com/a-polemic-by-nigel-glassborow / (accessed on 11 November 2017).

60. Lamb, W.F.; Steinberger, J.K. Human well-being and climate change mitigation. Wiley Interdiscip. Rev. Clim. Chang. 2017, 8. [CrossRef]

61. Gill, C. "Stoicism and the Environment" by Chris Gill. Available online: http://modernstoicism.com/ stoicism-and-the-environment-by-chris-gill/ (accessed on 11 November 2017).

62. Varki, A.; Altheide, T.K. Comparing the human and chimpanzee genomes: Searching for needles in a haystack. Genome Res. 2005, 15, 1746-1758. [CrossRef] [PubMed]

63. Prüfer, K.; Munch, K.; Hellmann, I.; Akagi, K.; Miller, J.R.; Walenz, B.; Koren, S.; Sutton, G.; Kodira, C.; Winer, R. The bonobo genome compared with the chimpanzee and human genomes. Nature 2012, 486, 527-531. [CrossRef] [PubMed]

64. Waters, C.N.; Zalasiewicz, J.; Summerhayes, C.; Barnosky, A.D.; Poirier, C.; Gałuszka, A.; Cearreta, A.; Edgeworth, M.; Ellis, E.C.; Ellis, M. The Anthropocene is functionally and stratigraphically distinct from the Holocene. Science 2016, 351. [CrossRef] [PubMed]

65. Irwin, T.H. Virtue, praise and success: Stoic responses to Aristotle. Monist 1990, 73, 59-79. [CrossRef]

66. Schofield, M. Cardinal virtues: A contested Socratic inheritance. In Plato and the Stoics; Long, A.G., Ed.; Cambridge University Press: Cambridge, UK, 2013; ISBN 978-1-107-04059-5.

67. Gawande, A. The Checklist Manifesto: How to Get Things Right; Macmillan: London, UK, 2011; ISBN 978-0-312-43000-9.

68. Whiting, K.; Carmona, L.G. A Critical Evaluation of Post-Normal Science's role in Climate Change Modelling and Political Decision-Making. Rev. Tecnol. 2014, 13, 28-38.

69. Brand-Correa, L.I.; Steinberger, J.K. A Framework for Decoupling Human Need Satisfaction From Energy Use. Ecol. Econ. 2017, 141, 43-52. [CrossRef]

70. Annas, J. Is Stoic Virtue as Off-Putting as it Seems? Available online: http://modernstoicism.com/is-stoicvirtue-as-off-putting-as-it-seems-by-julia-annas / (accessed on 11 November 2017).

71. Robertson, D. The System of Stoic Philosophy. Available online: http://modernstoicism.com/the-system-ofstoic-philosophy / (accessed on 11 November 2017).

72. Brundtland, G.H. Report of the World Commission on Environment and Development: "Our Common Future"; United Nations: New York, NY, USA, 1987.

73. Piketty, T. Capital in the 21st Century, 3rd ed.; Belknap Press: Cambridge, MA, USA, 2014.

74. Spash, C.L. Economics, ethics, and long-term environmental damages. Environ. Ethics 1993, 15, 117-132. [CrossRef]

75. Jackson, T. Material Concerns: Pollution, Profit, and Quality of Life; Psychology Press: Hove, UK, 1996; ISBN 0-415-13248-7.

76. Doyal, L.; Gough, I. A Theory of Human Need; Palgrave Macmillan: New York, NY, USA, 1991.

77. Richards, D.G. Eudaimonia, Economics and the Environment: What do the Hellenistic Thinkers Have to Teach Economists about "The Good Life"? Ethics Environ. 2013, 18, 33-53. [CrossRef]

78. Krausmann, F.; Wiedenhofer, D.; Lauk, C.; Haas, W.; Tanikawa, H.; Fishman, T.; Miatto, A.; Schandl, H.; Haberl, H. Global socioeconomic material stocks rise 23-fold over the 20th century and require half of annual resource use. Proc. Natl. Acad. Sci. USA 2017, 114, 1880-1885. [CrossRef] [PubMed]

79. Kahneman, D.; Knetsch, J.L.; Thaler, R.H. Anomalies: The endowment effect, loss aversion, and status quo bias. J. Econ. Perspect. 1991, 5, 193-206. [CrossRef]

80. Fieser, J. English Translation of the Enchiridion. Available online: http://www.sacred-texts.com/phi/epi/ enchir.txt (accessed on 15 December 2017).

81. Arieti, J.A. Philosophy in the Ancient World: An Introduction; Rowman \& Littlefield: Lanham, MD, USA, 2005; ISBN 0-7425-3329-8.

82. Wallace-Hadrill, A. The Other Pompeii: Life and Death in Herculaneum. 2013. Available online: http:/ / www. bbc.co.uk/programmes/b01rrld8 (accessed on 9 February 2018).

83. Rowan, E. Bioarchaeological preservation and non-elite diet in the Bay of Naples: An analysis of the food remains from the Cardo V sewer at the Roman site of Herculaneum. Environ. Archaeol. 2017, 22, 318-336. [CrossRef]

84. Waelkens, L. Amne Adverso: Roman Legal Heritage in European Culture; Leuven University Press: Leuven, Belgium, 2015; ISBN 94-6270-054-0. 
85. UNICEF. Undernutrition Contributes to Nearly Half of All Deaths in Children under 5 and Is Widespread in Asia and Africa. Available online: https:/ / data.unicef.org/topic/nutrition/malnutrition/\# (accessed on 11 November 2017).

86. Wallace-Hadrill, A. Building the Ancient City: Athens and Rome. 2015. Available online: http://www.bbc. co.uk/programmes/b067922h (accessed on 9 February 2018).

87. Bruun, C. Water supply, drainage and watermills. In The Cambridge Companion to Ancient Rome; Erdkamp, P., Ed.; Cambridge University Press: Cambridge, UK, 2013; pp. 306-307, ISBN 1-107-43381-9.

88. European Commission. Study on Water Performance of Buildings; European Commission: Brussels, Belgium, 2009.

89. United Nations Statistics. Division Proportion of the Population Using Improved Drinking Water Sources, Total. Available online: http:/ / data.un.org/Data.aspx?q=water\&d=MDG\&f=seriesRowID\%3a665 (accessed on 11 November 2017).

90. Smil, V. Why America Is Not a New Rome; MIT Press: Cambridge, MA, USA, 2010; ISBN 0-262-28829-X.

91. Bailey, D.M. A Sherd with a Painted Inscription from Monte Testaccio in Rome. Br. Mus. Q. 1965, 30, 40-41. [CrossRef]

92. Beard, M. SPQR: A History of Ancient Rome; Profile Books: London, UK, 2015; ISBN 1-84765-441-X.

93. Schofield, M. The Stoic Idea of the City; University of Chicago Press: Chicago, IL, USA, 1999; ISBN 0-226-74006-4.

94. Pigliucci, M. Cicero's Critique of Stoicism, Part I. Available online: https:/ /howtobeastoic.wordpress.com/ 2016/08/25/ciceros-critique-of-stoicism-i/ (accessed on 11 November 2017).

95. Gough, I. Recomposing consumption: Defining necessities for sustainable and equitable well-being. Phil. Trans. R. Soc. A 2017, 375, 20160379. [CrossRef] [PubMed]

(C) 2018 by the authors. Licensee MDPI, Basel, Switzerland. This article is an open access article distributed under the terms and conditions of the Creative Commons Attribution (CC BY) license (http://creativecommons.org/licenses/by/4.0/). 